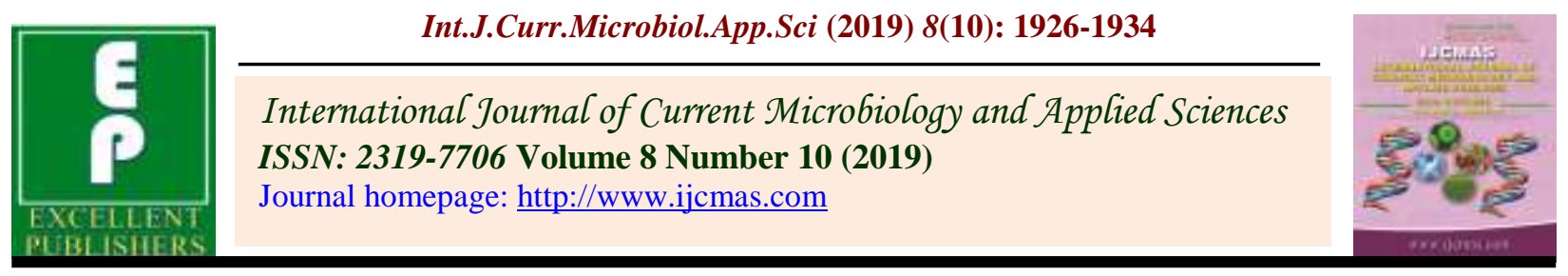

Original Research Article

https://doi.org/10.20546/ijcmas.2019.810.224

\title{
Drying Kinetics and Mathematical Modeling of Beetroot
}

\author{
Murlidhar Ingle ${ }^{1}$, Radhika Nawkar $^{1}$ and Shriram Godse ${ }^{2}$ \\ ${ }^{1}$ Krishi Vigyan Kendra, Badgaon-Balaghat, JNKVV, Jabalpur, 481115 (M.P.) India \\ ${ }^{2}$ Department of Food Science and Technology, Post Graduate Institute, Mahatma Phule \\ Krishi Vidyapeeth, Rahuri, Dist. Ahmednagar (Maharashtra) 413 722, India \\ *Corresponding author
}

\begin{tabular}{|l|}
\hline Key w o r d s \\
Beetroot, Drying, \\
Drying curve, \\
Drying rate, \\
Mathematical \\
models
\end{tabular}

\section{A B S T R A C T}

An attempt has been made to study the drying behavior of beetroot slices using cabinet dryer. The beetroot slices were dried at $50,55,60,65$ and $70 \pm 1{ }^{\circ} \mathrm{C}$ for $660,630,420,400$ and $390 \mathrm{~min}$ respectively. There was 36.36 per cent reduction in drying time as compared to 50 and $60^{\circ} \mathrm{C}$ temperature while it was 40.90 per cent at 60 to $70{ }^{\circ} \mathrm{C}$ temperature. The drying rate decreased with increase in drying time. The drying occurred mostly in falling rate period. The drying rates were as high as 0.9 at $65^{\circ} \mathrm{C}$ and as low as 0.1 at $55^{\circ} \mathrm{C}$. The drying curves were fitted by means of four different moisture ratio mathematical models that are widely used in most food and biological materials; namely, Henderson and Pabis, Logarithmic, Page and Modified Page. The best model describing the drying process was selected based on the low RMSE, $\chi^{2}$, high $R^{2}$ and adjusted $R^{2}$. The $R^{2}$ and adjusted $R^{2}$ values for the models were greater than 0.90 , indicating a good fit. The $R^{2}$ and adjusted $\mathrm{R}^{2}$ values for Logarithmic model were varied between 0.932 and $0.963,0.926$ and 0.960 respectively, $\chi^{2}$ values between 0.07 and 0.11 , and $R M S E$ values between 0.151 and 0.208 . The Logarithmic model was found to be a better model compared to other for describing the drying characteristics of beetroot at all temperatures.

\section{Introduction}

Beetroot (Beta vulgaris L.) belonging to the Chenopodiaceae family is indigenous to Asia and Europe. Beetroots are rich in carbohydrates, protein, fiber, minerals like iron potassium, magnesium, copper, calcium and potent antioxidants and betanin. Specific anti-carcinogens are bound to the red coloring matter, which supposedly helps to fight against cancer. Betanin is one of the approved food additives as a food colorant (E 162) and antioxidant (Sturzoiu et al., 2011). Beetroot predominately contains pigments called betalains, a class of betalamic acid derivatives which are composed of betacyanins and betaxanthins (Pitalua et al., 2010). The betalain and phenolic composition of red beetroot has been studied in detail by Kujala $e t$ al., (2000) and Kujala et al., (2002).

Beetroots are rich in valuable active compounds such as carotenoids (Dias et al., 2009), glycine betaine (de Zwart et al., 2003), saponins (Atamanova et al., 2005), betacyanines (Patkai et al., 1997), folates 
(Jastrebova et al., 2003), betanin, polyphenols and flavonoids (Vali et al., 2007). Therefore, beetroot ingestion can be considered a factor in cancer prevention (Kapadia et al., 1996).

Consumption of red beet having antioxidants can contribute to protection from age related diseases. Beetroot is one of the most potent vegetables with respect to antioxidant activity (Vinson et al., 1998, Zitnanova et al., 2006 and Georgiev et al., 2010). Betacyanins are a group of compounds exhibiting antioxidant and radical-scavenging activities (Escribano $e t$ al., 1998; Pedreno and Escribano, 2000). They also inhibit cervical ovarian and bladder cancer cells in vitro (Zou et al., 2005).

Betalains and other phenolic compounds present in red beet decreases oxidative damage of lipids and improve antioxidant status in humans. Antioxidant activity in red beet is associated with involvement of antioxidants in the scavenging of free radicals and consequently in the prevention of diseases like cancer and cardiovascular diseases (DelgadoVargas et al., 2000).

Fresh beetroots are exposed to spoilage due to their high moisture content. One of the preservation methods ensuring microbial safety of biological products is drying (Mathlouthi, 2001). Dried beetroots can be consumed directly in the form of chips as a substitute of traditional snacks, that are rich in trans fatty acids (Aro et al., 1998), or after easy preparation as a component of instant food (Krejčová et al., 2007). Decreasing the moisture content of fresh foods to make them less perishable is a simple way to preserve these foods.

Convective drying in hot air is still the most popular method applied to reduce the moisture content of fruits and vegetables (Lewicki, 2006), including beetroots (Kamin'ski et al., 2004 and Shynkaryk et al., 2008). However, this method has several disadvantages and limitations; for instance, it requires relatively long time and high temperatures, which causes degradation of important nutritional substances (Marfil et al., 2008) as well as color alteration (Chua et al., 2001). It also causes shrinkage due to tissue collapse caused by volume reduction due to the loss of moisture as well as the presence of internal forces (Mayor and Sereno, 2004).

Drying increases, the storage stability of fruits and vegetables making them available throughout the year.

\section{Materials and Methods}

\section{Raw materials and sample preparation}

Fresh and well matured beetroot were obtained from the local market of Rahuri, Dist. Ahmednagar. The beetroots were cleaned, washed, blanched (3-5 $\mathrm{min}$ at $80-90$ $\left.{ }^{\circ} \mathrm{C}\right)$, peeled and cut into thin slices $(3-5 \mathrm{~mm})$ using sharp knife.

The beetroot slices were spread in a single layer on a tray and dried at 50,55,60,65 and $70 \pm 1^{\circ} \mathrm{C}$ in a hot air cabinet dryer. The loss in weight was determined quickly after cooling using a laboratory weighing scale placed near the dryer. Readings were taken at a time interval of every $30 \mathrm{~min}$ till a constant weight was observed. The exact value for the respective temperature was assumed as the equilibrium moisture content in subsequent computations. Independent drying experiments were performed at various temperatures $\left(50\right.$ to $\left.70^{\circ} \mathrm{C}\right)$.

\section{Mathematical modeling}

The experimental drying data of beetroot at different drying temperatures were fitted into four commonly used thin-layer drying models (Table 1). Moisture ratio of samples during drying was generally calculated by the following equation: 


$$
M R=\frac{\mathrm{M}-\mathrm{Me}}{\mathrm{Mci}-\mathrm{Me}}
$$

where, MR is the dimensionless moisture ratio, $\mathrm{M}, \mathrm{Me}$ and Mci are the moisture content at any time ( $\mathrm{kg}$ water $/ \mathrm{kg} \mathrm{dm})$, the equilibrium moisture content $(\mathrm{kg}$ water $/ \mathrm{kg} \mathrm{dm})$ and the initial moisture content ( $\mathrm{kg}$ water $/ \mathrm{kg} \mathrm{dm}$ ) respectively (Wankhade et al., 2012).

\section{Correlation coefficients and error analysis}

The ability of the tested mathematical model to represent the experimental data was evaluated through the correlation coefficient $\left(\mathrm{R}^{2}\right)$, the reduced $\left({ }^{X^{2}}\right)$ and the root mean square error (RMSE) parameters.

The higher the $\mathrm{R}^{2}$ and lower the $\chi^{2}$ and RMSE values, the better is the fitting procedure (Wang et al., 2007 and Ozbek and Dadali, 2007). The regression analysis was performed by using the SAS software. These parameters are defined as follows:

$$
\begin{aligned}
& \chi 2=\sum \frac{(\operatorname{Mrpra,i}, \mathrm{M} \operatorname{Rexp}, \mathrm{i})^{2}}{\operatorname{MRpre,i}} \\
& \text { RMSE }=\left[\frac{\frac{1}{N} \sum_{\mathrm{i}=1}^{\mathrm{N}}(\text { MRexp }, \mathrm{i}-\text { MRpre }, \mathrm{i})^{2}}{N}\right]^{\frac{1}{2}}
\end{aligned}
$$

Where, MRexp, i and MRpre, $\mathrm{i}$ are the $i$ th experimental and predicted moisture ratio, respectively, $\mathrm{N}$ is the number of observations and $\mathrm{z}$ is the number of parameters.

\section{Moisture content (Mc)}

$M c=\frac{\mathrm{Mi}-\mathrm{Md}}{\mathrm{Mi}} \times 100$

$M i$ is the mass of sample before drying and $M d$ is the mass of sample after drying.

\section{Drying rate $(\mathbf{R d})$}

$R d=\frac{\mathrm{Mi}-\mathrm{Md}}{\mathrm{t}}$

$M i$ is the mass of sample before drying and $M d$ is the mass of sample after drying and ' $\mathrm{t}$ ' is time in min.

\section{Results and Discussion}

\section{Fitting of drying curves}

The moisture content of beetroot was decreased with increased drying time at various drying temperature. It showed that the moisture removal is rapid during the initial period of drying than in next phase of drying which shows constant rate for removal of moisture (Fig. 1). The moisture removal was influenced by surface area of the slices and also by drying temperature. The results revealed that as the drying temperature is increased the moisture removal is also increased which resulted in decrease in drying time. The drying time at 50, 55, 60, 65 and 70 ${ }^{\circ} \mathrm{C}$ drying temperature were $660,630,420$, 400 and $390 \mathrm{~min}$ respectively for beetroot slices.

\section{Drying rate}

The drying rate rapidly increases and then slowly decreases as drying progresses (Fig. 2). In general, it was observed that drying rate reduces with time or with the reduction of moisture content. The drying process took place in the falling rate period. Similar results have been observed in the drying of different fruits and vegetables: kiwifruit (Femenia et al., 2009); hazelnut (Uysal et al., 2009); carrot pomace (Kumar et al., 2011); pineapple, mango, guava and papaya (Marques et al., 2009) and apple pomace (Wang et al., 2007). The moisture content of the material was very high during the initial phase of the drying 
which resulted in a higher absorption of heat and higher drying rates due to the higher moisture diffusion. As the drying progressed, the loss of moisture in the product caused a decrease in the absorption of heat and resulted in a fall in the drying rate. This indicated that the drying temperature had a crucial effect on the drying rate. Similar findings were reported in previous studies (Wang et al., 2007; Soysal et al., 2006 and Therdthai and Zhou, 2009).

\section{Modeling of drying characteristics}

The first set of experiments was conducted to obtain moisture curves at different temperatures $\left(50\right.$ to $70^{\circ} \mathrm{C}$ ) as shown in Figure 1. Moisture content decreased from 90.86 per cent to 11.67 per cent at all the temperatures whereas the drying time decreased from 660to $360 \mathrm{~min}$, lowest time at highest temperature. The first step of modeling was to define drying curves for beet. Drying rate as function of moisture content was plotted (Fig. 2). After a short initial time of sample heating, constant rate drying was observed for some time. At lower drying temperatures, constant drying rate was lower and moisture kept on diffusing to the surface resulting in lower critical moisture content. Moisture ratio as a function of drying time is given in Figure 3. It can be seen that moisture ratio decreases exponentially with time.

The statistical results from models are summarized in Table 2. The four drying models were compared in terms of the statistical parameters $\mathrm{R}^{2}$, adjusted $\mathrm{R}^{2}, \chi^{2}$ and RMSE to describe the drying curves of beetroot slices at different temperatures. The best model describing the drying process was selected based on the low RMSE, low $\chi^{2}$, and high $\mathrm{R}^{2}$, adjusted $\mathrm{R}^{2}$. For the current experimental data, the $R^{2}$ values for the models were greater than 0.90 , indicating a good fit. The $R^{2}$ and adjusted $\mathrm{R}^{2}$ values for Logarithmic model was varied between 0.932 and $0.963,0.926$ and 0.960 respectively, $\chi^{2}$ values between 0.07 and 0.11 , and $R M S E$ values between 0.151 and 0.208 . Based on the criteria of the highest $\mathrm{R}^{2}$, adjusted $\mathrm{R}^{2}$, lowest RMSE and $\chi^{2}$, the Logarithmic model was selected as the most suitable model to represent the thin-layer drying behaviour of beetroot samples.

Table.1 Drying models

\begin{tabular}{|c|c|c|c|}
\hline Model No. & Name & Model Equation & \multicolumn{1}{|c|}{ References } \\
\hline $\mathbf{1}$ & Page & $\mathrm{MR}=\exp \left(-\mathrm{kt}{ }^{\mathrm{n}}\right)$ & Jangam et al., (2008) \\
\hline $\mathbf{2}$ & Modified Page & $\mathrm{MR}=\exp \left[-(\mathrm{kt})^{\mathrm{n}}\right]$ & Midilli et al., (2002) \\
\hline $\mathbf{3}$ & Henderson and Pabis & $\mathrm{MR}=\mathrm{a} \exp (-\mathrm{kt})$ & Figiel (2010) \\
\hline $\mathbf{4}$ & Logarithmic & $\mathrm{MR}=\mathrm{a} \exp (-\mathrm{kt})+\mathrm{c}$ & Kingsly et al., (2007) \\
\hline
\end{tabular}


Table.2 Results of the model fitting statistics of various thin layer drying models

\begin{tabular}{|c|c|c|c|c|c|c|c|c|c|c|}
\hline & Temp $\left({ }^{0} \mathrm{C}\right)$ & $\mathbf{k}$ & $\mathbf{n}$ & $\mathbf{R}^{2}$ & $\operatorname{Adj} \mathbf{R}^{2}$ & $\mathbf{P}$ & $\chi^{2}$ & RMSE & MBE & \% Error Modulus \\
\hline \multirow[t]{5}{*}{ Page } & 50 & $0.0954 \pm 0.0662$ & $-0.1715 \pm 0.0116$ & 0.912 & 0.908 & $1.4 \mathrm{E}-12$ & 0.029 & 0.045 & $1.93082 \mathrm{E}-16$ & 0.118 \\
\hline & 55 & $0.0895 \pm 0.0582$ & $-0.1539 \pm 0.0103$ & 0.918 & 0.914 & $2.5 \mathrm{E}-12$ & 0.017 & 0.0388 & 0.001693468 & 0.053 \\
\hline & 60 & $0.0795 \pm 0.0755$ & $-0.2288 \pm 0.0144$ & 0.955 & 0.951 & 1.9E-09 & 0.013 & 0.0401 & $2.53765 \mathrm{E}-16$ & 0.081 \\
\hline & 65 & $0.0773 \pm 0.0947$ & $-0.2099 \pm 0.0178$ & 0.914 & 0.908 & $2.6 \mathrm{E}-08$ & 0.022 & 0.0521 & $3.25665 \mathrm{E}-16$ & 0.123 \\
\hline & 70 & $0.0738 \pm 0.0923$ & $-0.2358 \pm 0.0178$ & 0.941 & 0.936 & $4.2 \mathrm{E}-08$ & 0.016 & 0.0472 & $2.03541 \mathrm{E}-16$ & 0.118 \\
\hline \multirow{6}{*}{$\begin{array}{l}\text { Modified } \\
\text { Page }\end{array}$} & 50 & $-0.5562 \pm 0.0662$ & $-0.1715 \pm 0.0116$ & 0.912 & 0.908 & $1.4 \mathrm{E}-12$ & 0.029 & 0.045 & $1.93082 \mathrm{E}-16$ & 0.120 \\
\hline & 55 & $-0.5815 \pm 0.0582$ & $-0.1539 \pm 0.0103$ & 0.918 & 0.914 & $2.5 \mathrm{E}-12$ & 0.018 & 0.0388 & $1.00929 \mathrm{E}-17$ & 0.070 \\
\hline & 60 & $-0.3475 \pm 0.0755$ & $-0.2288 \pm 0.0144$ & 0.955 & 0.951 & $1.9 \mathrm{E}-09$ & 0.013 & 0.0401 & $2.53765 \mathrm{E}-16$ & 0.080 \\
\hline & 65 & $-0.3683 \pm 0.0947$ & $-0.2099 \pm 0.0178$ & 0.914 & 0.908 & $2.6 \mathrm{E}-08$ & 0.022 & 0.0521 & $3.25665 \mathrm{E}-16$ & 0.120 \\
\hline & 70 & $-0.3128 \pm 0.0923$ & $-0.2358 \pm 0.0178$ & 0.941 & 0.936 & 4.2E-08 & 0.016 & 0.0472 & $4.44089 \mathrm{E}-16$ & 0.110 \\
\hline & Temp $\left({ }^{0} \mathrm{C}\right)$ & $\mathbf{k}$ & $\mathbf{a}$ & $\mathbf{R}^{2}$ & $\operatorname{Adj} \mathbf{R}^{2}$ & $\mathbf{P}$ & $\chi^{2}$ & RMSE & MBE & \% Error Modulus \\
\hline \multirow{5}{*}{$\begin{array}{c}\text { Henderson } \\
\text { and } \\
\text { Pabis }\end{array}$} & 50 & $-0.1715 \pm 0.0116$ & $10.4855 \pm 0.0662$ & 0.912 & 0.908 & 0 & 0.029 & 0.0450 & $1.93082 \mathrm{E}-16$ & 0.120 \\
\hline & 55 & $-0.1539 \pm 0.0103$ & $11.1721 \pm 0.0582$ & 0.918 & 0.914 & 0 & 0.018 & 0.0388 & $1.00929 \mathrm{E}-17$ & 0.070 \\
\hline & 60 & $-0.2288 \pm 0.0144$ & $12.5738 \pm 0.0755$ & 0.955 & 0.951 & 0 & 0.013 & 0.0401 & $2.53765 \mathrm{E}-16$ & 0.080 \\
\hline & 65 & $-0.2099 \pm 0.0178$ & $12.9343 \pm 0.0947$ & 0.914 & 0.908 & 0 & 0.022 & 0.0521 & $3.25665 \mathrm{E}-16$ & 0.120 \\
\hline & 70 & $-0.2358 \pm 0.0178$ & $13.5582 \pm 0.0923$ & 0.941 & 0.936 & 0 & 0.016 & 0.0472 & $4.44089 \mathrm{E}-16$ & 0.110 \\
\hline \multirow[t]{5}{*}{ Logarithmic } & 50 & $-0.7138 \pm 0.0393$ & $8.0546 \pm 0.2241$ & 0.94 & 0.937 & $2.5 \mathrm{E}-14$ & 0.11 & 0.1523 & $3.86 \mathrm{E}-16$ & 0.180 \\
\hline & 55 & $-0.7548 \pm 0.042$ & $8.9848 \pm 0.2381$ & 0.942 & 0.939 & $8.4 \mathrm{E}-14$ & 0.096 & 0.1584 & $7.47 \mathrm{E}-16$ & 0.130 \\
\hline & 60 & $-0.9487 \pm 0.0539$ & $8.8196 \pm 0.2834$ & 0.963 & 0.96 & $6.2 \mathrm{E}-10$ & 0.067 & 0.1505 & $2.37905 \mathrm{E}-15$ & 0.130 \\
\hline & 65 & $-0.9475 \pm 0.0712$ & $9.3326 \pm 0.3785$ & 0.932 & 0.926 & $6 \mathrm{E}-09$ & 0.113 & 0.2084 & $2.66454 \mathrm{E}-15$ & 0.230 \\
\hline & 70 & $-1.0186 \pm 0.066$ & $9.3377 \pm 0.3425$ & 0.956 & 0.952 & 8.5E-09 & 0.075 & 0.175 & $1.1273 \mathrm{E}-15$ & 0.180 \\
\hline
\end{tabular}


Fig.1 Moisture content of beetroot slices influenced by drying time at different drying temperatures

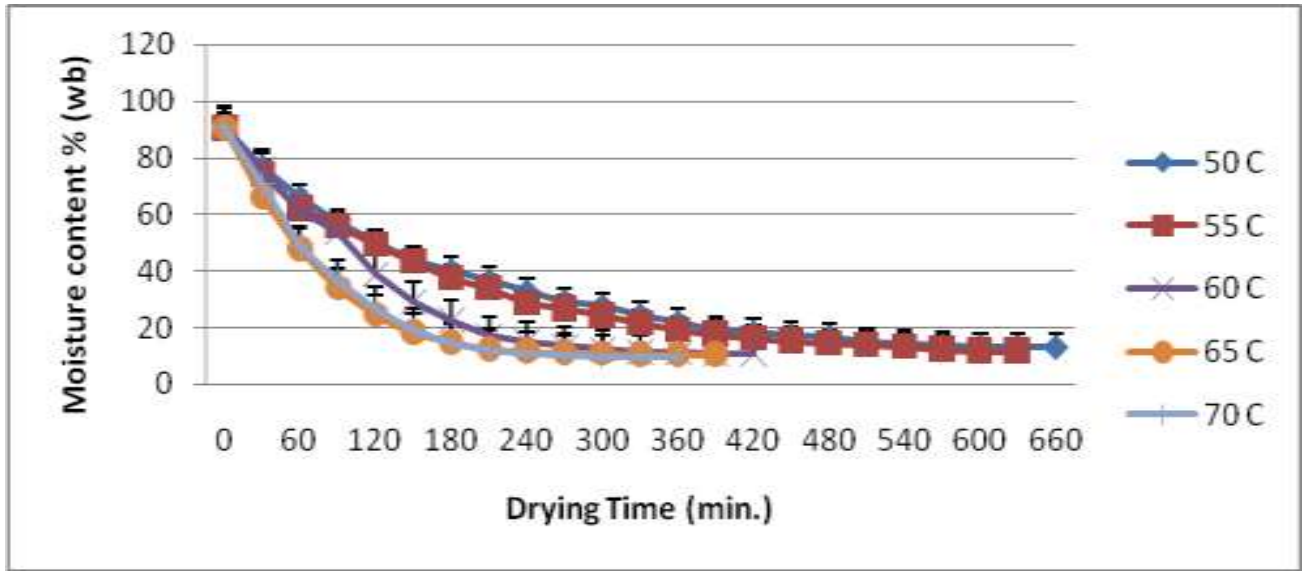

Fig.2 Drying rate of beetroot slices influenced by drying time at different drying Temperatures

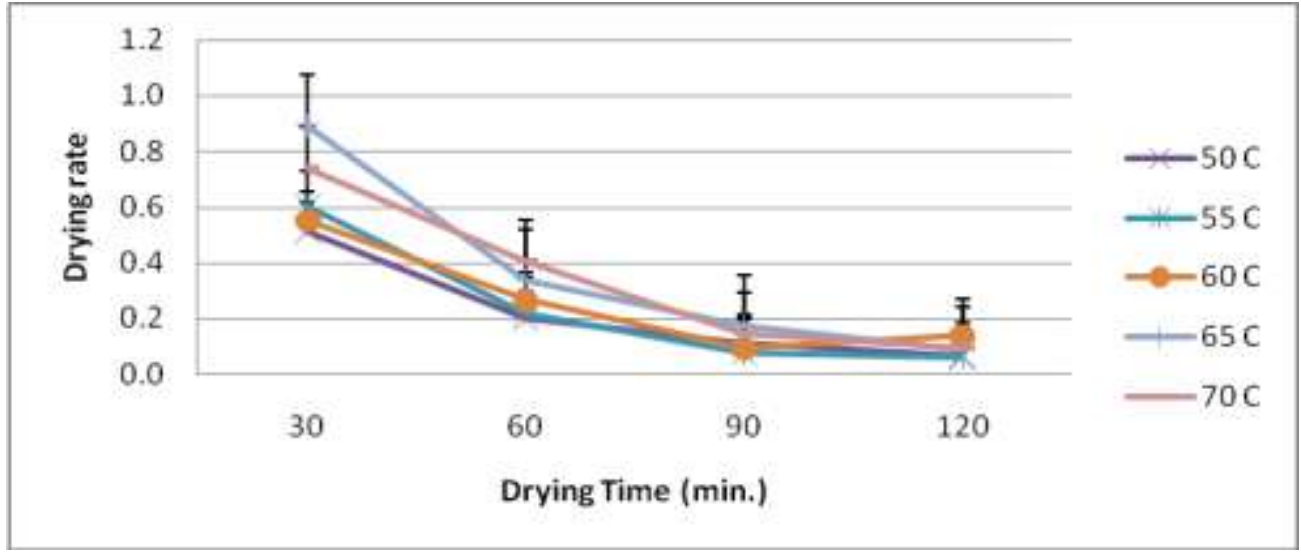

Fig.3 Moisture ratio of drying of beetroot slices influenced by drying time at different drying temperatures

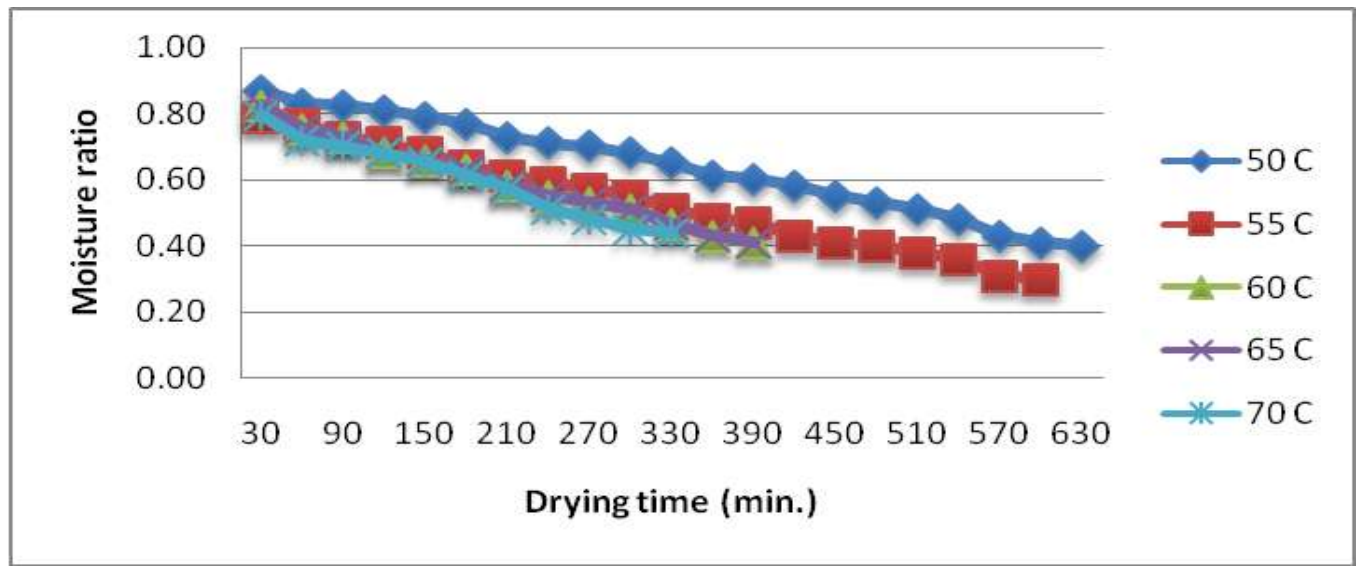


In conclusion, the drying characteristic of beetroot under hot air was studied. The increase in air drying temperature decreased the drying time. Total drying time considerably reduced with the increase in drying air temperature. Drying took place in the falling rate period. Based on the findings in the present experiment it can be concluded that Logarithmic model was found to be a better model for describing the drying characteristics of beetroot at all temperatures. Finally, it can be concluded that thin layer drying can be used for the preparation and preservation of beetroot slices.

\section{References}

Aro A, Amaral E, Kesteloot H, Rimestad A and Thamm M (1998). Trans Fatty Acids in French Fries, Soups, and Snacks from 14 European Countries: The Transfer Study. Journal of Food Composition and Analysis 11: 170-177.

Atamanova A, Brezhneva TA, Slivkin AI, Nikolaevskii VA, Selemenev VF and Mironenko NV (2005). Isolation of saponins from table beetroot and primary evaluation of their pharmacological activity. Pharma Chem Journal39 (12):650-652.

Chua KJ, Mujumdar AS, Hawlader MNA, Chou SK and Ho JC (2001). Batch drying of banana pieces - effect of stepwise change in drying air temperature on drying kinetics and product color. Food Research International34:721-731.

De Zwart FJ, Slow S, Payne RJ, Lever M, George PM, Gerrard JA and Chambers ST (2003). Glycine betaine and glycine betaine analogues in common foods. Food Chemistry. 83:197-204.

Delgado VF, Jimenez AR and Paredes L O (2000). Natural pigments: Carotenoids, anthocyanins, and betalains characteristics, biosynthesis, processing, and stability. Critical Reviews in Food Science and Nutrition 40: 173-289.

Dias MG, Camoes MFGFC and Oliveira L (2009). Carotenoids in traditional Portuguese fruits and vegetables. Food Chemistry 113: 808-815.

Escribano J, Pedreno MA, Garcia-Carmona F and Munoz R (1998). Characterization of the antiradical activity of betalains from Beta vulgaris L. roots, Phytochemical Analysis 9: 124-127.

Femenia A, Sastre-Serrano G, Simal S, Garau MC, Eim VS and Rossello C (2009). Effects of air-drying temperature on the cell walls of kiwifruit processed at different stages of ripening. $L W T-F o o d$ Sci. Technol, 42:106-112.

Figiel A (2010). Drying kinetics and quality of beetroots dehydrated by combination of convective and vacuum-microwave methods. Journal of Food Engineering 98 (4): 461-470.

Georgiev VG, Weber J, Kneschke EM, Nedyalkov DP, Bley $\mathrm{T}$ and Pavlov AI (2010). Antioxidant activity and phenolic content of betalain extracts from intact plants and hairy root cultures of the red beetroot Beta vulgaris $c v$. detroit dark red, Plant Foods for Human Nutrition65:105-111.

Jangam SV, Joshi VS, Mujumdar AS and Thorat BN (2008). Studies of dehydration of sapota (Achraszapota). Drying Technology, 26: 369-377.

Jastrebova J, Witthoft C, Grahn A, Svensson $U$ and Jagerstad M (2003). HPLC determination of folates in raw and processed beetroots. Food Chemistry80: 579-588.

Kamin' ski W, Tomczak E and Skorupska E (2004). Estimation of the effect of shape and temperature on drying kinetics using MLP. Drying Technology22 (1 and 2):191-200.

Kapadia GJ, Tokuda H, Konoshima T and Nishino H (1996). Chemoprevention of 
lung and skin cancer by Beta vulgaris (beet) root extract. Cancer Letters 100: 211-214.

Kingsly RP, Goyal RK, Manikantan MR and Ilyas SM (2007). Effects of pretreatments and drying air temperature on drying behavior of peach slice. International Journal of Food Science and Technology42: 6569.

Krejčová A, Cernohorsky T and Meixner D (2007). Elemental analysis of instant soups and seasoning mixtures by ICPOES. Food Chem, 105: 242-247.

Kujala TS, Loponen JM, Klika KD and Pihlaja K (2000). Phenolics and betacyanins in red beetroot (Beta vulgaris) root: Distribution and effect of cold storage on the content of total phenolics and three individual compounds. Journal of Agricultural and Food Chemistry, 48: 5338-5342.

Kujala TS, Vienola MS, Klika KD, Loponen JM and Pihlaja K (2002). Betalains and phenolic compositions of four beetroots (Beta vulgaris) cultivars. Eur Food Res Technol., 214: 505-510.

Kumar N, Sarkar BC and Sharma HK (2011). Effect of air velocity on kinetics of thin layer carrot pomace drying. Food Sci TechnolInt, 17:439-447.

Lewicki PP (2006). Design of hot air drying for better foods. Trends in Food Science and Technology, 17:153-163.

Marfil PHM, Santos EM and Telis VRN (2008). Ascorbic acid degradation kinetics in tomatoes at different drying conditions. LWT-Food Science and Technology, 41:1642-1647.

Marques LG, Prado MM and Freire JT (2009). Rehydration characteristics of freeze-dried tropical fruits. $L W T-$ Food Sci Technol., 42: 1232-1237.

Mathlouthi M (2001). Water content, water activity, water structure and the stability of foodstuffs. Food Control 12: 409-
417.

Mayor L and Sereno AM (2004). Modeling shrinkage during convective drying of food materials: a review. Journal of Food Engineering, 61: 373-386.

Midilli A, Kucuk H and Yapar Z (2002). A new model for single layer drying. Drying Technol, 20(7): 1503-1513.

Ozbek B and Dadali G (2007). Thin-layer drying characteristics and modeling of mint leaves undergoing microwave treatment. Journal of Food Engineering, 83: 541-549.

Patkai G, Barta J and Varsanyi I (1997). Decomposition of anticarcinogen factors of the beetroot during juice and nectar production. Cancer Letters, 114:105-106.

Pedreno MA and Escribano J (2000). Studying the oxidation and the antiradical activity of betalain from beetroot. Journal of Biological Education, 35(1): 49-51.

Pitalua E, Jimenez M, Vernon-Carter EJ and Beristain CI (2010). Antioxidative activity of microcapsules with beetroot juice using gum Arabic as wall material. Food and Bioproducts Processing, 88: 253-258.

Shynkaryk MV, Lebovka NI and Vorobiev E (2008). Pulsed electric fields and temperature effects on drying and rehydration of red beetroots. Drying Technology26 (6):695-704.

Soysal A, Oztekin S and Eren O (2006). Microwave drying of parsley: modelling, kinetics, and energy aspects. Biosyst Engg, 93(4):403-413.

Therdthai N and Zhou W (2009). Characterization of microwave vacuum drying and hot air drying of mint leaves (Mentha cordifolia OPIZEXFResen). J Food Engg91:482-489.

Uysal N, Sumnu G and Shin S (2009). Optimization of microwave- infrared roasting of hazelnut. J Food Engg., 90: 
226-255.

Vali L, Stefanovits BE, Szentmihalyi K, Febel H, Sardi E, Lugasi A, Kocsis I and Blazovics A (2007). Liver-protecting effects of table beet (Beta vulgaris var. Rubra) during ischemia-reperfusion. Nutrition, 23: 172-178.

Vinson JA, Hao Y, Su X and Zubik L (1998). Phenol antioxidant quantity and quality in foods: Vegetables. Journal of Agricultural and Food Chemistry, 46: 3630-3634.

Wang Z, Sun J, Chen F, Liao X and Hu X (2007). Mathematical modelling on thin layer microwave drying of apple pomace with and without hot air predrying. J Food Engg., 80:536-544.
Wankhade PK, Sapkal RS and Sapkal VS (2012). Drying characteristics of okra slices using different drying methods by comparative evaluation, Proceedings of the World Congress on Engineering and Computer Science 2012 Vol II.

Zitnanova I, Ranostajova S, Sobotova H, Demelova D, Pechan I and Durackova $\mathrm{Z}$ (2006). Antioxidative activity of selected fruits and vegetables. Biologia, 61:279-284.

Zou D, Brewer M, Garcia F, Feugang JM, Wang J and Zang R (2005). Cactus pear: A natural product in cancer chemoprevention. Nutrition Journal, $4: 25$.

\section{How to cite this article:}

Murlidhar Ingle, Radhika Nawkar and Shriram Godse. 2019. Drying Kinetics and Mathematical Modeling of Beetroot. Int.J.Curr.Microbiol.App.Sci. 8(10): 1926-1934.

doi: https://doi.org/10.20546/ijcmas.2019.810.224 